DOI: https://doi.org/10.11144/Javeriana.upsy18-1.esbd

\title{
Energy-Saving Behavior: the Different Roles of Altruism and of Environmentalism*
}

\section{Comportamiento de Ahorro de Energía: Diferentes Roles del Altruismo y del Ambientalismo}

Received: 23 April 2016 | Accepted: 11 November 2018

\author{
Ana Loureiro \\ Universidade Lusófona, Portugal \\ ORCID: http://orcid.org/0000-0002-8587-5513 \\ MARIA LuÍ́sa Lima \\ Universidade de Lisboa, Portugal \\ ORCID: http://orcid.org/0000-0003-1171-2962
}

$\begin{array}{ll}\text { a Correspondence author. } & \text { Email: } \\ \text { ana.loureiro@ulusofona.pt }\end{array}$

How to cite: Loureiro, A., \& Lima, M. L. (2019). Energy-saving behavior: The different roles of altruism and of environmentalism. Universitas Psychologica, 18(1), 1-12. https://doi.org/10.11144/Javeriana.upsy 18-1.esbd

\begin{abstract}
This experimental study, in which 118 university students participated, addresses how environmental and altruistic cues induce energy-saving behavior and intention, and their interaction with environmental and altruistic values, thus testing the influence of context or situational variables in energy-saving behavior and intention. Additionally, it does an empirical approach to the role that environmental and altruistic values may have as individual predictors of energy-saving. Environmental and altruistic situational cues are operationalized by environment and altruism conceptual priming. The results reveal an interaction between situational variables and personal values: environment priming induced more energysaving behavior among individuals with lower altruistic values. The same effect is not observed for energy-saving intention. When the environment and altruism priming were present, individuals with lower altruistic values had less energy-saving intentions. These results underline the importance of distinguishing environmental and altruistic frames and motives when explaining energy-saving behavior.
\end{abstract}

Keywords

energy saving; altruism; environmentalism; priming; values.

\section{RESUMEN}

Este estudio experimental, en el que participaron 118 estudiantes universitarios, investiga cómo las pistas ambientales y altruistas inducen el comportamiento de ahorro energético, e interactúan con los valores ambientales y altruistas, examinando la influencia de variables de contexto o situacionales en estos comportamientos e intenciones, y el papel de estos valores como predictores de ahorro energético. El priming conceptual de ambiente y de altruismo operacionaliza las pistas situacionales. Los resultados revelan una interacción entre las variables situacionales y los valores personales: el priming de ambiente indució más comportamiento de ahorro energético entre los individuos con valores altruistas inferiores. El mismo efecto no se observa para la intención. Cuando el priming de ambiente y de altruismo estaba presente, los individuos con valores altruistas menores tuvieron menos intenciones de ahorro energético. Estos resultados subrayan la importancia de distinguir 
marcos y motivos ambientales y altruistas al explicar el comportamiento de ahorro energético.

Palabras clave

ahorro de energía; altruismo; ecologismo; priming; valores.

Today, climate change and environmental problems associated are among the biggest challenges facing humankind. Energy consumption is presented as one of the most important causes of these problems. Technological improvements allow the reduction of energy consumption, but there is also a need for changes in consumption patterns and human behavior (Kempton, Darley \& Stern, 1992; Oskamp, 2000; van de Ven, GonzálezEguino \& Arto, 2018; Vlek \& Steg, 2007).

The study of the psycho-social determinants of pro-environmental behavior, as the case of energy saving, has identified several effects (Gatersleben, Steg \& Vlek, 2002; Tapia-Fonllem, Corral-Verdugo \& Fraijo-Sing, 2017; Jakovcevic, Díaz-Marín, Moreno, Geiger, \& Tonello, 2013; Vining \& Ebreo, 2002). Both individual values or attitudes (Fransson \& Gärling, 1999; Bamberg \& Möser, 2007), and situational variables, such as context cues or social norms, have explained pro-environmental behaviour (Black, Stern \& Elworth, 1985; Corraliza \& Berenguer, 2000; Guagnano, Stern \& Dietz, 1995).

Part of the past research, based on Schwartz' values theory (Schwartz, 1992), has demonstrated that universalism and benevolence values (related to self-transcendence) are positively associated with pro-environmental beliefs, attitudes and behavior (Lima, Marques, \& Moreira, 2012; Howell, 2013; Schultz \& Zelezny, 1999). This research has also shown that self-enhancement values appear to be negatively correlated with environmental attitudes and behavior (Karp, 1996). These associations appear for different types of environmental behavior, such as buying/consumption intentions (Honkanen \& Verplanken, 2004), environmental activism (Coelho, Gouveia \& Milfont, 2006), and general pro-environmental measures that include recycling and energy conservation (Hansla,
Gamble, Juliusson \& Gärling, 2008; Nordlund \& Garvill, 2002; Schultz et al., 2005).

Some studies tried to identify the role of environmental values, which are associated with universalism and obtained a stronger association between environmental values and pro-environmental behavior than between other values included in universalism (Schultz \& Zelezny, 1998). On the other hand, even when the environmental component of universalism values is not considered in the analysis of the relation between values and pro-environmental behavior, the relationship between selftranscendence values and environmental behavior is shown (López, Álvarez, González, \& García, 2015; Schultz et al., 2005). Others obtained an association between benevolence values and socio-altruistic environmental attitudes and between universalism values and biospheric (environmental) attitudes (Hansla et al., 2008). These results support the idea that it is essential to distinguish the specific role of the environmental dimension from the other components of universalism values.

Value-Belief-Norm (VBN) Theory (Stern, 2000; Stern \& Dietz, 1994; Stern, Dietz, Abel, Guagnano \& Kalof, 1999) is a theoretical approach that distinguishes between three value orientations related to environmental behavior: biospheric (environmental), altruistic and egoistic. This theory is supported by empirical research (Barr, 2007; DeGroot \& Steg, 2008; Nordlund \& Garvill, 2003; Schultz, 2001; Stern, Dietz \& Guagnano, 1995). Several findings illustrate how biospheric and altruistic value orientations relate positively to different types of pro-environmental behavior. Despite the evidence for the association between these value orientations and behavior, the distinction between the specific roles of those different value orientations and how the process is developed has not always been made. In some studies, it was found that biospheric, altruistic and egoistic value orientations were related to pro-environmental behavior (Stern, Dietz, \& Kalof, 1993). Steg, Dreijerink and Abrahamse (2005) studied the acceptability of energy policies, applying the VBN theory, and found 
that biospheric values mainly explained proenvironmental behaviors. They pointed out the importance of distinguishing between the role of biospheric and that of altruistic values when explaining pro-environmental behavior. Some researchers tried to make this distinction and found that while this behavior was more strongly associated with biospheric values, it was still significantly associated with altruistic values (Clark, Kotchen, \& Moore, 2003; DeGroot, $\&$ Steg, 2010). Even in the context of this theoretical approach, however, other studies did not distinguish between biospheric and altruistic values and, therefore, did not refer to them as distinct value orientations (Stern \& Dietz, 1994; Stern, Dietz \& Guagnano, 1995). In this sense, the particular roles of environmental and altruistic values still need to be clarified.

Situational variables have been associated with pro-environmental behavior. Several findings show that individual factors interact with situational variables in the prediction of pro-environmental behavior and those situational variables may facilitate or inhibit pro-environmental behavior (e.g., Corraliza \& Berenguer, 2000; Guagnano et al., 1995). For example, studying different kinds of energy-related behavior, Black, Stern and Elworth (1985) found that structural conditions constrained the influence of individual variables on behavior.

More specifically, different types of situational factors may influence the impact of values on behaviour (Maio, Olson, Bernard \& Luke, 2003). This effect may be studied using priming methodologies, testing the automatic effects of different mental representations on individual judgments, perceptions or even behaviors (Drijksterhuis \& Bargh, 2001). Relevant situational cues may automatically activate judgment or behavioral response to certain situations. Priming effects on behavior are due to the activation of associative links between the concepts mentally represented and specific behavioral responses (Drijksterhuis, Aarts, Bargh \& Knippenberg, 2000).

Research using priming showed that value activation leads to behavior consistent with those values. For example, Verplanken and Holland (2002) conducted a range of experimental studies investigating values as predictors of a specific pro-environmental behavior: environmentally friendly consumption choice behavior. Using a priming paradigm for the activation of environmental values, they showed that value activation had a consistent effect on behavior when those values were central for the individual self-concept. The authors' selfactivation hypothesis posits that values that are part of the self-concept (meaning they are central for the individual) predict behavior better when they are activated in a context.

Because both environmental and altruistic values may be associated with pro-environmental behavior, it is essential to study the effects of situational activation for both concepts. The study of the distinct role of individual values, from the role of situational cues, is important as it may contribute for giving insights for the design of more efficient and suited interventions for sustainable behaviors promotion. Also, the use of both behaviours and intentions as dependent variables is important for better clarification of the role of the independent variables situational cues, and its interaction with values. Therefore, the objective of the present research is then to study whether environmental and altruistic situational cues induce energy-saving behavior and intention and how they interact with individual environmental and altruistic values.

To address our objective, we follow an experimental approach that enables us to analyze whether situational cues to environment and altruism concepts influence energy-saving behavior and intention. The activation of environment and altruism situational cues is operationalized in the study through a conceptual priming paradigm (Bargh \& Chartrand, 2000).

In what concerns the effect of the activation of situational cues, we expected the priming of both environment and altruism concepts to have a positive effect on energy saving behavior and intention. We also investigated whether individual values moderate the predictor effect of conceptual priming on behavior and intention, so 
that environment priming would have a positive effect on energy saving mainly for those with stronger and more central environmental values, and altruism priming to have a positive effect on energy saving mainly for those with stronger and more central altruistic values.

\section{Method}

\section{Design and Participants}

The design of this study was a 2 (Environment priming: Present vs. Absent) X 2 (Altruism priming: Present vs. Absent) betweenparticipants factorial design. A total of 118 students at a Portuguese university (94 female and 22 male) participated in the study. The average age was 22 years ( $S D=4.5$ years). Participants were randomly assigned to each of the four priming conditions: 30 participants in the environment priming, 28 in the altruism priming, 29 in the environment plus altruism priming and 29 in the control condition (no priming). The study was carried out following the American Psychological Association ethical principles.

\section{Materials}

\section{Activation of situational cues}

The activation of environment and altruism situational cues on energy saving behavior was implemented through conceptual priming (Bargh $\&$ Chartrand, 2000). The priming consisted of a scrambled sentence task (Srull \& Wyer, 1979) for priming environment and altruism. This task was presented as a verbal aptitude test and consisted of 30 scrambled sentences of five words each. In each scrambled sentence (for example "cold - goes - water - the - is"), the participant had to remove one word and write a four-word grammatically correct sentence (in this case "the water is cold"). The environment priming included 20 scrambled sentences with a word referring to the environment (e.g., earth, water, climate, recycling) and in the other 10 scrambled sentences, no word was related with the environment. In the altruism priming, 20 scrambled sentences included one word referring to altruism (e.g., help, voluntary, dedication, solidarity). The words for the environment and altruism priming are presented in the Appendix. The priming words were never the ones to be removed from the scrambled sentences. In the environment plus altruism priming condition, with 60 scrambled sentences, participants did both priming tasks. The 30 scrambled sentences of the control task did not include words that referred to the environment or altruism (e.g., ball, letter, musician). The word selection for priming tasks was based on other priming tasks and measures for environmental beliefs and altruistic behavior used in published work (Batson et al., 1997; Dunlap, VanLiere, Mertig, \& Jones, 2000; Rushton, Chrisjohn, \& Fekken, 1981; Verplanken \& Holland, 2002; Walther, Müller, \& Schott, 2001; Yavuzer et al., 2006).

The effectiveness of this priming task was pretested. Following the scrambled sentence task, participants were asked to freely associate to the word "news". In this pilot test, 75 participants were randomly assigned to the two priming tasks and the control task, and each production of the free association was classified by two independent judges as associated to environmental topics (e.g., "pollution"), altruistic ones (e.g., "voluntary psychologists") or to none of these. Each participant could give multiple associations. Significantly more associations with the environment were made in the environment priming task condition $(\mathrm{M}=0.66, \mathrm{SD}=1.21$, range from 0 to 5), than when no environment priming $(\mathrm{M}=0.05, \mathrm{SD}=0.23), F(1,71)=$ $8.584, p<0.01$, eta $s q=0.11$. Also, significantly more associations were made with altruism in the altruism priming condition $(\mathrm{M}=0.43, \mathrm{SD}=$ 0.69 , range from 0 to 2$)$, than when no altruism priming was used $(M=0.16, S D=0.44), F(1,71)$ $=4.642, p<0.05$, eta ${ }^{2}=0.06$. 
Values

For the measurement of environmental and altruistic values, we used the Portuguese version of the most recent values scale by Schwartz, named PVQ - Portrait Values Questionnaire (Schwartz et al., 2001, as cited in Ramos, 2006). Participants are instructed to indicate their perceived individual similarity to several portraits ("A woman/man who really believes that people should protect nature. Protecting the environment is important for them"; "A woman/ man for whom it is important to help those around them. They enjoy looking after their wellbeing"). Two items were added to the original scale, one for assessment of environmental values ("A woman/man to whom union with nature is important") and the other for the assessment of altruistic values ("A woman/man to whom it is important to help others. When she/he helps, she/he does not expect to be rewarded"). By recommendation of the scale's author, the scores obtained are centered, subtracting the total scale mean from the value of the items mean. The two value measures presented good internal consistency (environmental values, $r=$ $0.735, p<0.01, \alpha=0.85$; altruistic values, $r=$ $0.556, p<0.01, \alpha=0.71$ ).

\section{Energy saving behavior}

Three behaviors were measured as indicators of energy saving behavior: whether or not participants turned off the light of the experimental room, whether or not they turned off the table lamp, and whether or not they turned off the air conditioning when they left the room. Two of these behaviors (light of the room and air conditioning) were the energy-related behaviors usually available in classrooms, and the third one (table lamp) was available at the lab room table used for the experimental tasks. The lab room had no natural light. The frequency of each of these energy-saving behaviors was noted after the participant had left the experimental room.

\section{Energy saving intention}

To measure energy saving intention we used 5 items indicating energy-saving behaviour intention at university ("to turn off the computer when my work is finished") and at home ("to turn off lights when leave the room"; "to turn off the mobile phone and computer adaptors when not in use"; "to turn off the computer when my work is finished"; "to turn off the printer when I stop working") $(\alpha=.61)$. For each item, respondents had to indicate whether they intended to do the action in the following week, scored in a scale from 1 (never) to 5 (always), using 0 for "not applicable".

\section{Procedure}

The study took place in two different rooms. The participant entered the first darkened room with the experimenter (who ostensively turned on the light of the room, the table lamp and the air conditioning). The experimenter gave the instructions for the priming task completion (presented as a verbal aptitude test) and informed the participant that he or she should meet him in a nearby room when finished. The participant had thus the opportunity to turn off the lights and air conditioning of the first room. In the second room, the participant returned the sheets of the priming task to the experimenter and she proposed to the student the participation in a second different study on the psychometric qualities of an instrument. All the participants accepted and completed a questionnaire including the measures of environmental and altruistic values, energy saving intention and demographic data. While the participant was completing the questionnaire, the energy saving behaviour in the first room was measured. In the end, participants were probed about the relationship between the two studies, and about the identification of any common type of words in the scrambled sentence task (adapted from Chartrand \& Bargh, 1996). In this debriefing, two participants revealed that they perceived something about the study's 
objectives, so they were excluded from the analysis.

\section{Results}

Results are presented in two parts: first, we report the analysis of the effects of the manipulation of situational activation of environmental and altruistic cues, and the moderator effect of environmental and altruistic values, on energysaving behavior, and then for energy saving intention.

\section{Priming, Values, and Energy Saving Behaviour}

$49.1 \%$ of the participants turned off the light of the experimental room, and $65.5 \%$ of the participants turned off the table lamp. Due to the very low percentage of participants who turned off the air conditioning (1.7\%), this behavior was excluded from the analysis. Air conditioning is not a very used behavior by students at classrooms, and this may be the reason why participants at the experiment barely performed it. An index of energy saving behaviour was computed to be used as a dependent variable (sum of energy saving behaviours: $0=$ no behavior; $1=$ one behavior; $2=2$ behaviors).

Before conducting the analyses of the interaction effects between environment and altruism priming and environmental and altruistic values, the effect of gender was tested, and no significant association with energy saving behavior was found.

Four multiple regression analyses were conducted, with the index of energy saving behaviors as the dependent variable. Following the recommendations of Aiken and West (1991) for analyzing moderating effects in regression models, two dummy variables were created, one for the environment and other for the altruism priming. Scores of the moderators, environmental and altruistic values were also centered and kept as continuous variables.

First, the interaction between priming (environment and altruism) and environmental values was analysed. This was done by testing two models. In the first model environment and altruism priming entered as predictors as well as the interaction term, and in the second one environmental values was added as a predictor, as well as their interaction terms. No effects were found, neither for environment and altruism priming, Adj $^{2} R^{2}=0.005, F(3,112)=1.202, p=$ 0.31 , nor for the interaction with environmental values, $\operatorname{Adj}^{2} R^{2}=-0.007, F(7,108)=0.887, p=$ 0.52 .

The same procedure was followed for the analysis of the interaction between primings and altruistic values. The first model was the same as for the previous analysis. For the interaction between priming and altruistic values, although the general prediction of the model is not significant, $A_{d j} R^{2}=0.028, F(7,108)=1.478$, $p=0.18$, the estimated parameters indicate that the interaction between environment priming and altruistic values is significant, $\beta=-0.405$; $t(108)=-2.573, p<0.05$, and the interaction between environment priming, altruism priming and altruistic values is marginally significant, $\beta$ $=0.264 ; t(108)=1.727, p=0.087$. Simple slope analyses were used to break down the significant interaction. Single effects indicate that environment priming predicts the increase of energy saving behaviour for participants with lower altruistic values, $\beta=0.56 ; t(108)=2.82$, $p<0.01$, but not for participants with higher altruistic values, $\beta=-0.15 ; t(108)=-0.80$, $p=0.43$, and that this only happens when there is no altruism priming. With no altruism priming, participants with lower altruistic values performed more energy saving behaviors in the environment priming condition than in the no environment priming condition (Figure 1). For altruism priming, no effects were significant. In this condition, simple slope analyses indicate that environment priming does not predict energysaving behavior for participants with lower altruistic values, $\beta=0.04 ; t(108)=0.022, p$ $=0.83$, or for participants with higher altruistic values, $\beta=0.03 ; t(108)=0.14, p=0.89$ (Figure 1). 
Figure 1

Energy saving behavior as a function of environment priming, altruism priming and altruistic values.

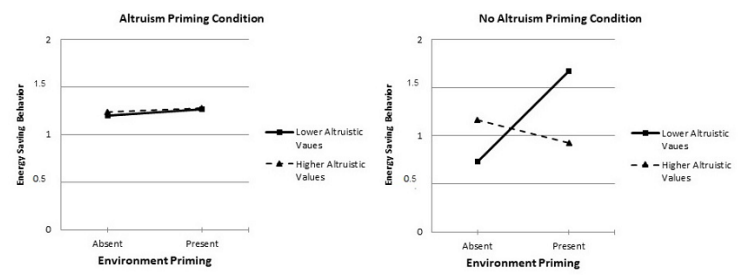

Priming, Values, and Energy Saving Intention

Regarding behavioral intention, participants showed considerable intention to engage in energy saving behavior $(M=4.16, S D=$ 0.69). The correlation between energy saving intention and energy saving behavior is $r=$ $0.109, p=0.27$. For these analyses, the index of energy saving intention entered as the dependent variable (scale from 0 to 5 ), and we followed the same procedures as in the previous section for analyzing moderating effects in regression models (Aiken \& West, 1991).

For the interaction between priming (environment and altruism) and environmental values, no effects were found, neither for environment and altruism priming, Adj $R^{2}=$ $-0.013, F(3,101)=.571, p=0.64$, nor for the interaction with environmental values, $\operatorname{Adj} R^{2}=$ $0.030, F(7,97)=0.562, p=0.79$.

The two models were tested for the analysis of the interaction between primings and altruistic values. The interaction between environment priming, altruism priming, and altruistic values had a significant effect on energy saving intention, $\operatorname{Adj}^{2}=0.121, F(7,97)=3.039$, $p<0.01$. The estimated parameters indicate that the interaction between environment priming, altruism priming, and altruistic values is significant, $\beta=0.363 ; t(97)=2.361, p<0.05$. Simple slope analyses were used to break down the significant interaction. Single effects indicate that environment priming marginally predicts the lesser energy saving intention for participants with lower altruistic values, $\beta=-0.34 ; t(108)$ $=-1.75, p=0.08$, but not for participants with higher altruistic values, $\beta=0.25 ; t(108)=1.28$, $p=0.20$, but this only happens with altruism priming at the same time. Participants with lower altruistic values are those who have less energy saving intention (Figure 2). For no altruism priming, no significant effects were found. Simple slope analyses indicate that environment priming does not predict energy saving intention for participants with lower altruistic values, $\beta=$ $0.20 ; t(108)=0.97, p=0.34$, or for participants with higher altruistic values, $\beta=-0.16 ; t(108)=$ $-0.90, p=0.37$ (Figure 2).

\section{Figure 2}

Energy saving intention as a function of environment priming, altruism priming, and altruistic values.

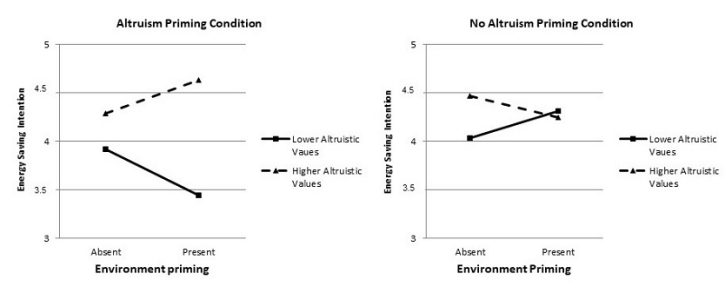

\section{Discussion}

The research objectives were to study whether environmental and altruistic situational cues induce energy-saving behavior and intention, as well as the effects of the interaction between these cues and individual environmental and altruistic values. No significant principal effects for priming of environment and altruism were obtained, but we did find several results related to the interaction between priming and values.

We obtained reliable interactions between environment priming and altruistic values. Globally, participants with lower altruistic values engaged in more energy saving behaviors with environment priming. This result supports the idea that situational variables interact with individual characteristics and may be important factors for the explanation and promotion of proenvironmental behavior (Corraliza \& Berenguer, 
2000; Guagnano et al., 1995; Spence, Leygue, Bedwell, \& O'Malley, 2014).

The present findings follow a different pattern from the findings of the studies by Verplanken and Holland (2002) that showed that environment priming was more effective in the production of pro-environmental choice behavior for those individuals with higher environmental values. A possible explanation for this difference resides in the type of task used in our study. The type of task in Verplanken and Holland's study (2002), a decision-making task, requires a level of cognitive reasoning that may result from deeper processing that would engage the values activated. Instead, our study measures observed and direct behaviors. In this case, the energy saving behaviors performed by participants seem to be more directly related to the effects of situational cues, which occur especially when the value level is lower. In this context of lower personal values, situational cues determined more energy saving behavior, and the results suggest that priming compensates the lower level of values (Corraliza \& Berenguer, 2000; Howes \& Gifford, 2009). In the absence of values, an inducing behavior context can be effective in the elicitation of behavior, without the need of a more conscious process.

The present research results related to priming and energy saving intention may contribute to reinforcing this explanation. Participants with lower altruistic values were those who showed the lesser energy saving intention, in the presence of environment and altruism priming. In these conditions, where a more conscious cognitive process was demanded, we do not find the same pattern of results as for energy-saving behavior, where priming was effective for those with lower values. For energy saving intention, the presence of values should have been important for the decision of intention (Verplanken \& Holland, 2002).

Taken together, our results suggest that situational cues and personal values play a role and that the interaction between them must be considered when explaining and promoting pro-environmental behavior, in particular, the promotion of energy saving in contexts such as domestic or public environments. The focus on how situational cues promote pro-environmental behavior when we are in the presence of lower levels of social values could show how context framing may be effective in this behavioral promotion (Wu, DiGiacomo \& Kingstone, 2013). Also, the results of the presented study reinforce the idea that existing values must be considered when planning interventions to promote pro-environmental behaviors (Steg, Bolderdijk, Keizer, \& Perlaviciute, 2014; Stern, 2000). Contextual frames were effective mainly in eliciting behaviors (more than intentions) and in the case of lower levels of individual values. This means that situational frames and cues can be usefull strategies for promoting sustainable behavior, especially in the absence of individual determinants as values. More, they are effective in promoting behavior without cognitive demand processes as those associated with the decision of intentions.

The present study used an environment and altruism conceptual priming. The extension to other types of contexts, namely using images with environmental and altruistic content is an interesting domain of future research. The distinction between less and subtler situational cues could give more insight into the processes by which contextual characteristics interact with personal variables on behaviors and decisions.

The present findings contribute to the study of the role of environmental and altruistic frames and motives in the explanation of energy-saving behavior, stressing the importance of differentiating these two concepts when studying pro-environmental behavior, as well as their interaction with personal variables as environmental and altruistic values.

\section{References}

Aiken, L. S., \& West, S. G. (1991). Multiple regression: Testing and interpreting interactions. London: Sage Publications.

Bamberg, S., \& Möser, G. (2007). Twenty years after Hines, Hungerford, and Tomera: A new meta-analysis of psycho- 
social determinants of pro-environmental behaviour. Journal of Environmental Psychology, 27(1), 14-25. https://doi.org/10. 1016/j.jenvp.2006.12.002

Bargh, J. A., \& Chartrand, T. L. (2000). The mind in the middle: A practical guide to priming and automaticity research. In $\mathrm{H}$. T. Reis \& C. Rudd (Eds.), Handbook of research methods in social and personality psychology (pp. 253-285). Cambridge: Cambridge University Press.

Barr, S. (2007). Factors influencing environmental attitudes and behaviours: A U.K. case study of household waste management. Environment and Behavior, 39(4), 435-473. https://doi.org/10.1177/00 13916505283421

Batson, C. D., Sager, K., Garst, E., Kang, M., Rubchinsky, R., \& Dawson, K. (1997). Is empathy-induced helping due to self-other merging? Journal of Personality and Social Psychology, 73(3), 495-509. http://dx.doi.or $\mathrm{g} / 10.1037 / 0022-3514.73 .3 .495$

Black, J. S., Stern, P. C., \& Elworth, J. T. (1985). Personal and contextual influences on household energy adaptations. Journal of Applied Psychology, 70(1), 3-21. http://dx.d oi.org/10.1037/0021-9010.70.1.3

Chartrand, T. L., \& Bargh, J. A. (1996). Automatic activation of impression formation and memorization goals: Nonconscious goal priming reproduces effects of explicit task instructions. Journal of Personality and Social Psychology, 71(3), 464-478.

Clark, C. F., Kotchen, M. J., \& Moore, M. R. (2003). Internal and external influences on pro-environmental behaviour: Participation in a green electricity program. Journal of Environmental Psychology, 23(3), 237-246. https://doi.org/ 10.1016/S0272-4944(02)00105-6

Coelho, J. A., Gouveia, V. V., \& Milfont, T. L. (2006). Valores humanos como explicadores de atitudes ambientais e intenção de comportamento próambiental. Psicologia em Estudo, 11(1), 199-207.
Corraliza, J. A., \& Berenguer, J. (2000). Environmental values, beliefs, and actions: A situational approach. Environment and Behavior, 32 (6), 832-848. https://doi.org/10 $.1177 / 00139160021972829$

DeGroot, J. I., \& Steg, L. (2008). Value orientations to explain beliefs related to environmental significant behaviour: How to measure egoistic, altruistic, and biospheric value orientations. Environment and Behavior, 40(3), 330-354. https://doi.or g/10.1177/0013916506297831

DeGroot, J. I., \& Steg, L. (2010). Relationships between value orientations, self-determined motivational types and pro-environmental behavioural intentions. Journal of Environmental Psychology, 30(4), 368-378. https://doi.org/10.1016/j.jenvp.20 10.04 .002

Drijksterhuis, A., Aarts, H., Bargh, J. A., \& Van Knippenberg, A. (2000). On the relation between associative strength and automatic behaviour. Journal of Experimental Social Psychology, 36(5), 531-544. https://doi.org/ 10.1006/jesp.2000.1427

Drijksterhuis, A., \& Bargh, J. A. (2001). The perception-behaviour expressway: Automatic effects of social perception on social behaviour. Advances in Experimental Social Psychology, 33, 1-40. https://doi.org/1 0.1016/S0065-2601(01)80003-4

Dunlap, R. E., Van Liere, K. D., Mertig, A. G., \& Jones, R. E. (2000). Measuring endorsement of the New Ecological Paradigm: A revised NEP scale. Journal of Social Issues, 56(3), 425-442. https://doi.org /10.1111/0022-4537.00176

Fransson, N., \& Gärling, T. (1999). Environmental concern: Conceptual definitions, measurement methods, and research findings. Journal of Environmental Psychology, 19(4), 369-382. https://doi.org/ 10.1006/jevp.1999.0141

Gatersleben, B., Steg, L., \& Vlek, C. (2002). Measurement and determinants of environmentally significant consumer behaviour. Environment and Behavior, 34(3), 
335-362. https://doi.org/10.1177/00139165 02034003004

Guagnano, G. A., Stern, P. C., \& Dietz, T. (1995). Influences on attitude-behaviour relationships: A natural experiment with curbside recycling. Environment and Behavior, 27(5), 699-718. https://doi.org/10 $.1177 / 0013916595275005$

Hansla, A., Gamble, A., Juliusson, A., \& Gärling, T. (2008). The relationships between awareness of consequences, environmental concern, and value orientations. Journal of Environmental Psychology, 28(1), 1-9. https: //doi.org/10.1016/j.jenvp.2007.08.004

Honkanen, P., \& Verplanken, B. (2004). Understanding attitudes towards genetically modified food: The role of values and attitude strength. Journal of Consumer Policy, 27(4), 401-420. https://do i.org/10.1007/s10603-004-2524-9

Howell, R. A. (2013). "It's not (just) the environment, stupid!" Values, motivations, and routes to engagement of people adopting lower-carbon lifestyles. Global Environmental Change, 23(1), 281-290. https://doi.org/10.1016/j.gloenvc ha.2012.10.015

Howes, Y., \& Gifford, R. (2009). Stable or dynamic value importance? The interaction between value endorsement level and situational differences on decision-making in environmental issues. Environment and Behavior, 41(4), 549-582. https://doi.org/10.1177/00139165 08318146

Jakovcevic, A., Díaz-Marín, J., Moreno, C., Geiger, S., \& Tonello, G. (2013). Valores y cuidado de la energía: Implicancias para la educación ambiental en Argentina y Colombia. Revista Latinoamericana de Psicología, 45(3), 389-400. https://doi.org/1 $0.14349 /$ rlp.v45i3.1481

Karp, D. G. (1996). Values and their effect on pro-environmental behaviour. Environment EO Behavior, 28(1), 111-33. https://doi.org/1 $0.1177 / 0013916596281006$

Kempton, W., Darley, J. M., \& Stern, P. C. (1992). Psychological research for the new energy problems: Strategies and opportunities. American Psychologist, 47(10), 1213-1223.

Lima, M. L., Marques, S., \& Moreira, S. (2012). "A house in the woods": Values, attitudes and behaviours towards forests. Psyecology, 2, 87-100. https://doi.org/10.1174/2171197 11794394662

López, M. J., Álvarez, P., González, E., \& García, M. J. (2015). Medidas del comportamiento ecológico y antecedentes: conceptualización y validación empírica de escalas. Universitas Psychologica, 14(1), 189-204.https://doi.org/10.11144/Ja veriana.upsy14-1.mcea

Maio. G. R., Olson, J. M., Bernard, M. M., \& Luke, M. A. (2003). Ideologies, values, attitudes, and behaviour. In J. Delamater (Ed.), Handbook of social psychology (pp. 283-308). Boston, MA: Springer. https://do i.org/10.1007/0-387-36921-X_12

Nordlund, A. M., \& Garvill, J. (2002). Value structures behind proenvironmental behaviour. Environment and Behavior, 34(6), 740-756. https://doi.org/10.1177/00139160 2237244

Nordlund, A. M., \& Garvill, J. (2003). Effects of values, problem awareness, and personal norm on willingness to reduce personal car use. Journal of Environmental Psychology, 23(4), 339-347. https://doi.org/10.1016/S0 272-4944(03)00037-9

Oskamp, S. (2000). A sustainable future for humanity? How can Psychology help? American Psychologist, 55(5), 496-508. http s://doi.org/10.1037//0003-066X.55.5.496

Ramos, A. (2006). Social values dynamics and socio-economic development. Portuguese Journal of Social Science, 5(1), 35-64. https: //doi.org/10.1386/pjss.5.1.35/1

Rushton, J. P., Chrisjohn, R. D., \& Fekken, G. C. (1981). The altruistic personality and the self-report altruism scale. Personality and Individual Differences, 2(4), 293-302. https: //doi.org/10.1016/0191-8869(81)90084-2

Schultz, P. W. (2001). The structure of environmental concern: concern for self, other people, and the biosphere. Joumal of 
Environmental Psychology, 21(4), 327-339. h ttps://doi.org/10.1006/jevp.2001.0227

Schultz, P. W., Gouveia, V. V., Cameron, L. D., Tankha, G., Schmuck, P., \& Franěk, M. (2005). Values and their relationship to environmental concern and conservation behaviour. Journal of CrossCultural Psychology, 36(4), 457-475. https:/ /doi.org/10.1177/0022022105275962

Schultz, P. W., \& Zelezny, L. C. (1998). Values and pro-environmental behaviour: A fivecountry survey. Journal of Cross-cultural Psychology, 29(4), 540-558. https://doi.org/ 10.1177/0022022198294003

Schultz, P. W., \& Zelezny, L. C. (1999). Values as predictors of environmental attitudes: Evidence for consistency across 14 countries. Journal of Environmental Psychology, 19(3), 255-265. https://doi.org/ 10.1006/jevp.1999.0129

Schwartz, S. H. (1992). Universals in the content and structure of values: Theoretical advances and empirical tests in 20 countries. Advances in Experimental Social Psychology, 25, 1-65. https://doi.org/10.101 6/S0065-2601(08)60281-6

Schwartz, S. H., Melech, G., Lehmann, A., Burgess, S., Harris, M., \& Owens, V. (2001). Extending the cross-cultural validity of the theory of basic human values with a different method of measurement. Journal of Cross-cultural Psychology, 32(5), 519-542. https://doi.org/10.1177/00220221 01032005001

Spence, A., Leygue, C., Bedwell, B., \& O'Malley, C. (2014). Engaging with energy reduction: Does a climate change frame have the potential for achieving broader sustainable behaviour? Journal of Environmental Psychology, 38, 17-28. https:/ /doi.org/10.1016/j.jenvp.2013.12.006

Srull, T. K., \& Wyer, R. S. (1979). The role of category accessibility in the interpretation of information about persons: Some determinants and implications. Journal of Personality and Social Psychology, 37(10), 1660-1672. http://dx.doi.org/10.1037/0022 $-3514.37 .10 .1660$
Steg, L., Bolderdijk, J. W. , Keizer, K., \& Perlaviciute, G. (2014). An integrated framework to encouraging proenvironmental behaviour. The role of values, situational factors and goals. Journal of Environmental Psychology, 38, 104-115. h ttps://doi.org/10.1016/j.jenvp.2014.01.002

Steg, L., Dreijerink, L., \& Abrahamse, W. (2005). Factors influencing the acceptability of energy policies: A test of VBN theory. Journal of Environmental Psychology, 25(4), 415-425. https://doi.org/10.1016/j.jenvp.20 05.08 .003

Stern, P. C. (2000). Toward a coherent theory of environmentally significant behaviour. Journal of Social Issues, 56(3), 407-424. http s://doi.org/10.1111/0022-4537.00175

Stern, P. C., \& Dietz, T. (1994). The value basis of environmental concern. Journal of Social Issues, 50(3), 65-84. https://doi.org/10.1111 j. 1540-4560.1994.tb02420.x

Stern, P. C., Dietz, T., Abel, T., Guagnano, G. A., \& Kalof, L. (1999). A Value-Belief-Norm theory of support for social movements: The case of environmentalism. Human Ecology Review, 6(2), 81-97. Retrieved from http://www.jstor.org/stable/24707060

Stern, P. C., Dietz, T., \& Guagnano, G. A. (1995). The new ecological paradigm in social-psychological context. Environment and Behavior, 27(6), 723-743. https://doi.or g/10.1177/0013916595276001

Stern, P. C., Dietz, T., \& Kalof, L. (1993). Value orientations, gender, and environmental concern. Environment and Behavior, 25(5), 322-348. https://doi.org/10.1177/00139165 93255002

Tapia-Fonllem, C., Corral-Verdugo, V., \& FraijoSing, B. (2017). Sustainable behavior and quality of life. In G. Fleury-Bahi, E. Pol, \& O. Navarro (Eds.), Handbook of environmental psychology and quality of life research (pp. 173-184). Switzerland: Springer. https://doi.org/10.1007/978-3-31 9-31416-7_9

van de Ven, D. J., González-Eguino, M., \& Arto, I. (2018). The potential of behavioural change for climate change mitigation: 
A case study for the European Union. Mitigation and Adaptation Strategies for Global Change, 23(6), 853-886. https://doi. org/10.1007/s11027-017-9763-y

Verplanken, B., \& Holland, R. W. (2002). Motivated decision making: Effect of activation and self-centrality of values on choices and behaviour. Journal of Personality and Social Psychology, 82(3), 434-447. https ://doi.org/10.1037//0022-3514.82.3.434

Vining, J. \& Ebreo, A. (2002). Emerging theoretical and methodological perspectives on conservation behaviour. In R. B. Bechtel \& A. Churchman (Eds.), Handbook of environmental psychology (pp. 541-558). New York, NY: John Wiley \& Sons.

Vlek, C., \& Steg, L. (2007). Human behaviour and environmental sustainability: Problems, driving forces, and research topics. Journal of Social Issues, 63(1), 1-19. https://doi.org/10.1111/j.15404560.2007.00493.x

Walther, E., Müller, D., \& Schott, O. (2001). Automatisches soziales verhalten: Wie wirkt sich die aktivierung der konzepte egoismus und altruismus auf hilfeleistung aus? Zeitschrift für Experimentelle Psychologie, 48(3), 248-257. http://dx.doi.org/10.1026// 0949-3946.48.3.248

Wu, D. W., DiGiacomo, A., \& Kingstone, A. (2013). A sustainable building promotes pro-environmental behavior: An observational study on food disposal. PLoS ONE. https://doi.org/10.1371/journal.pone .0053856

Yavuzer, H., İşmen-Gazıŏlu, E., Yildiz, A., Demir, I. Mesici, F., Kiliçaslan, A., \& Sertelin, Ç. (2006). The teacher altruism scale: Development, validity and reliability. Educational Sciences: Theory EF Practice, 6(3), 964-972.

\section{Appendix A}

Words for Environment and Altruism Priming

\begin{tabular}{ll}
\hline \multicolumn{1}{c}{ Priming } & Words \\
\hline \multicolumn{1}{c}{ Environment } & \multicolumn{1}{c}{ Altruism } \\
\hline water & helps \\
tree & to help \\
biodegradable & friendship \\
biological & support \\
climate & charity \\
ecological & good \\
energy & fireman \\
flowers & dedication \\
forest & disinterest \\
garden & detachment \\
nature & generous \\
ocean & hospitable \\
bird & equality \\
planet & justice \\
beach & others \\
recyclable & doctor \\
recycling & nurse \\
sun & solidarity \\
earth & voluntary \\
green & volunteering \\
\hline
\end{tabular}

\section{Notes}

* Research article. This research was financially supported by a grant from the Portuguese Foundation for Science and Technology, Grant Number SFRH/ $\mathrm{BD} / 31357 / 2006$ at ISCTE-IUL. We thank our research team colleagues, and José Antonio Corraliza and Jaime Berenguer at the Universidad Autónoma de Madrid, for their helpful comments on earlier versions of this work. 